Emotional Intelligence and Effective Leadership

\title{
The Relationship between Emotional Intelligence and Effective Leadership of the First-Line Nurse Managers
}

\author{
Sally Mohammed Farghaly, Demonstrator
}

Nursing Administration, Faculty of Nursing, Alexandria University.

Zeinab Mohamed Nabawy, Professor

Nursing Administration, Faculty of Nursing, Alexandria University.

Laila Helmy Ossman, Assistant Professor

Psychiatric Nursing and Mental Health, Faculty of Nursing, Alexandria University

\begin{abstract}
Background: The concept of emotional intelligence is a variable that has recently gained much popularity as a potential underlying attribute of effective leadership. Objective: The aim of the present study is to identify the relationship between emotional intelligence and effective leadership. Setting: The study has been carried out in all in-patient medical $(N=23)$ and surgical $(N=15)$ units at Alexandria Main University Hospital. Subjects: Subjects included "200" staff nurses and 38 "first line nurse managers". Tools: Two tools were used namely, "Wong and Law Emotional Intelligence Scale” (WLEIS), and "the Multifactor Leadership Questionnaire” (MLQ 360 degree feedback). Results: Results of this study provide evidence to support the idea that emotional intelligence is positively related to the transformational leadership style, leadership effectiveness, and transactional leadership. Recommendations: Recommendations of this study are geared towards developing emotional intelligence among different levels of nursing administrators through enhancing working environments with open communication between staff and their managers, fostering team building and motivation.
\end{abstract}

\section{Introduction}

The First-line nurse manager is the most important person in nursing services. Most of her functions are concerned with supervision, leadership, development of morale, interest, and satisfaction in work on the part of the personnel in her unit $^{(1,2)}$. First-line nurse manager translates the goals and objectives of the department into actions ${ }^{(3)}$. Effective leadership requires using a variety of interpersonal techniques to create the best outcome in a given situation. Regardless of which techniques are used, if leaders have created successful and trusting relationships with their subordinates, then they will most likely be perceived as effective ${ }^{(4)}$. 
Effective leaders lead by example and merely invite others to come along with them. Keeping promises is another sign of effective leadership. They believe in others and never fail to reward or compliment them when they see they are doing well. Effective leaders admit when they are wrong and admit when they make mistakes. They can admit when they are wrong and by doing so, allow people to feel comfortable asking them for help and advice $^{(5)}$. Roche (2011) discussed effective leadership in terms of the ability to articulate a vision, motivate and support individuals, and behave ethically. It may be argued that these particular skills and behaviors associated with effective leadership require emotional awareness and intelligence ${ }^{(6)}$. One variable that has recently gained much popularity as a potential underlying attribute of effective leadership is the concept of emotional intelligence. Emotional intelligence has been widely defined as one's ability to identify and manage one's own emotions, as well as to understand and empathize with the emotions of others ${ }^{(4)}$.

Goleman, Boyatzis, and Mckee (2002) have argued that emotional intelligence is a critical component of effective leadership particularly as leaders deal with subordinates. Emotionally intelligent leaders serve as a benefit to subordinates in two ways: they motivate the followers to work together toward the organizational goals and also serve as a transformational influence over followers. In this manner, leader challenge the followers to work toward increasing their effectiveness and performance, facilitate the followers' interaction dynamics, build interpersonal trust, and inspire them to implement the articulated vision $^{(7)}$.

Emotional Intelligence (El) is a form of intelligence that involves the ability to recognize and regulate emotions in ourselves and others ${ }^{(8,9)}$. It reflects the ability to read and understand others in social context, to detect the nuances of emotional reactions, and to utilize such knowledge to influence others through emotional regulation and control. As such, it represents a critically important competency for effective leadership and individual performance in health care organizations today.

Increasingly, organizations are recognizing the need for emotionally intelligent individuals to ensure long-term success for such organizations. Emotional intelligence is recognized as more than a collection of professional abilities. It is a set of mental abilities that involves understanding, managing, perceiving, and using a person's emotions $^{(1)}$.

Wong et al. (2004) define emotional intelligence as a set of activities that a person uses to understand, regulate and make use of his/her own emotions ${ }^{(3)}$. It includes four 
dimensions namely, the appraisal and expression of emotion in oneself; appraisal and recognition of emotion in others; regulation of emotion in oneself; and use of emotion to improve performance. Selfemotions Appraisal which means the appraisal and expression of self-emotions that relates to an individual's ability to understand his or her deep emotions and express them naturally. Most people with the ability to express themselves naturally sense and acknowledge their emotions better. Others-emotions Appraisal refers to the appraisal and recognition of emotion in others that relates to an individual's ability to perceive and understand the emotions of people. Individuals who rate highly in this ability will be very sensitive to the emotions of others and predict the emotional responses of others. Regulation of Emotion which means the regulation of emotion in oneself that relates to the ability of a person to regulate his or her emotions, enabling a more rapid recovery from psychological mood swings either positive or negative. A person with high ability in this area would be able to return quickly to a normal psychological state after rejoicing or experiencing distress. People who rate highly in this ability would be less likely to lose their temper. Use of Emotion which means the use of emotion to improve performance that relates to an individual's ability to make use of his or her emotions by directing them toward constructive activities and personal performance. A person who is highly capable in this dimension maintains positive emotions most of the time and is able to encourage himor herself to do better continuously ${ }^{(3,9)}$.

Emotional intelligence is more relevant to important work-related outcomes such as individual performance, organizational productivity, and developing people because its principles provide a new way to understand and assess the behaviors, management styles, attitudes, interpersonal skills, and potential of people. It is an increasingly important consideration in human resource planning, job profiling, recruitment interviewing and selection, learning and development, and client relations and customer service ${ }^{(10)}$.

Emotional Intelligence contributes to people's capacity to work effectively in teams, manage stress, and/or lead others. Leaders who are poor at perceiving emotions may unknowingly miss important emotional signals from their co-workers. Similarly, leaders who are poor at managing their own emotions may allow emotions to interfere with effective action. Emotional intelligence skills help in developing leaders with effective leadership behaviors and an increased understanding of the impacts of emotions within a team or organization $^{(11)}$. Goleman (2002) believed that having a larger repertoire of emotional intelligence strengths can make a leader more effective because it means that the leader is 
flexible enough to handle the wide-ranging demands of running an organization ${ }^{(7)}$.

Over the past 20 years, there has been considerable interest in the new paradigm of transformational and transactional leadership. Previous leadership models have fallen short in explaining a "full range" of leadership styles, ranging from the charismatic and inspirational leaders to avoidant laissez-faire leaders ${ }^{(5)}$. In addition, interpersonal skills have become more integral to effective leadership; where leaders were once seen to control, plan and inspect the overall running of an organization. In today's, leadership roles are also to motivate and inspire others, to foster positive attitudes at work, and to create a sense of contribution and importance with and among employees ${ }^{(4)}$. As a result, researches have been exploring the underlying attributes and behaviors of leaders who successfully perform these contemporary leadership roles ${ }^{(12,13)}$. With the recent emergence of emotional intelligence as a characteristic of effective leadership and organizational performance, there are now two distinctive lines of research into leadership effectiveness and performance: the first is the measure of transformational and transactional leadership style, and the second is the measure of emotional intelligence as a characteristic of effective leadership $(14,15)$. Presently there is very limited descriptive and/or empirical research combining the traditional measures of leadership styles/behaviors and emotional intelligence. Each line of research has identified unique characteristics of effective leaders and their influence on organizational success, yet do successful leaders exhibit both transformational/transactional leadership styles and emotional intelligence as intrinsic and extrinsic abilities to lead effectively ${ }^{(16,17)}$. A study done by Bass and Avolio (2004) suggested that emotional intelligence as measured by the ability to monitor and manage emotions within one self and others may be an underlying competency of transformational leadership ${ }^{(18)}$.

Studies carried out in Egypt were limited to investigate leadership behavior and its relation with nurses' outcome; organizational commitment as well as leadership development program, while the relationship between the emotional intelligence and the leadership effectiveness has less attention $^{(15,19)}$. Moreover, exactly how, and to what extent emotional intelligence accounts for effective leadership is currently unknown and there is little research published that has explicitly examined this relationship. Popular claims regarding the extent to which emotional intelligence accounts for effective leadership skills are at present misleading.

Despite the misleading nature of such claims, popular literature has sought to highlight the utility of this potential relationship, and drawn important theoretical 
links between emotional intelligence and leadership performance ${ }^{(19-22)}$. Knowledge regarding exactly how emotional intelligence relates to leadership may lead to significant advances in leadership training and development programs, and the ability to select potentially effective leaders ${ }^{(15)}$.

So, the aim of the present study is to identify the relationship between emotional intelligence and effective leadership among first line nurse managers.

\section{Aim of Study}

The aim of the study is to: Identify the relationship between emotional intelligence and effective leadership among first line nurse managers.

\section{$\underline{\text { Research Question }}$}

What is the relationship between emotional intelligence and effective leadership of the first-line nurse managers?

\section{Materials and Method}

\section{Materials}

Design: A descriptive correlational design was used in this study.

Settings: This study was carried out in all Inpatient medical and surgical units and its subspecialties at Alexandria Main University Hospital that is equipped with 1724 beds distributed over different medical and surgical units. In addition, it provides a wide range of ambulatory care services such as: Out-Patient, Pharmacy, Emergency, X-ray, Physiotherapy, Teaching Center; and Paramedical Services as Dietary, Laundry and Maintenance. All hospital departments provide a non-paying service except for one floor (the 6th floor) which provides private paid service for medical and surgical inpatients. The hospital also includes an educational building (The new university hospital) which provides a medical and surgical health care and a wide range of ambulatory services. It is a private hospital for all departments consisting of nine floors which provide health care for private and health insurance.

Numbers of inpatient units included in the study were 38 units: 23 medical and 15 surgical units. All inpatient units include almost similar number of patients' rooms that range from five to six with each room containing about 8 beds.

Nurses working in these units were 205 in surgical and 235 in medical units. The average number of working nurses per unit ranged from 9 to 20 nurses in medical units, and from 9 to 18 nurses in surgical units during the morning shift.

Subjects: The subjects of the study included:

1. All first-line nurse mangers who were working in medical and surgical in-patient care units with its sub-specialties and were available at the time of data collection $(\mathrm{N}=38)$. 
2. Fifty per cent of all staff nurses, who had work relation with first-line nurse managers in the previously mentioned units and were available at the time of data collection $(\mathrm{N}=200)$.

Tools: The study used two tools for data collection namely: Wong and Law Emotional Intelligence Scale (WLEIS), and the Multifactor Leadership Questionnaire (MLQ 360 degree feedback).

\section{Tool (I): Tool 1: Wong and Law Emotional Intelligence Scale (WLEIS)}

Wong and Law Emotional Intelligence Scale (WLEIS) was developed by Wong and Law (2004) as a self-assessment tool to measure an individual's emotional intelligence $^{(3)}$. A modified version of the WLEIS was developed by (Macik-Frey, 2007) to gather information regarding subordinates' assessment of their manager's emotional intelligence $^{(11)}$. For example, statements such as "I have good control over my own emotions" were rewritten to say, "I believe my manager has good control over his/her own emotions". The two versions of the scale were used in the present study. The original draft (self-assessment) was used for first line nurse managers, while modified one was used for staff nurses to evaluate their managers.

The WLEIS consisted of 16 items, four items for each of the four dimensions of the El namely: Self-emotions Appraisal (SEA),
Others'-emotions Appraisal (OEA), Regulation of Emotion (ROE), and Use of Emotion (UOE). Responses were measured on a seven point likert scale ranging from (1) strongly disagree to (7) strongly agree. Scores were calculated for each of the four subscales by average scores of the respondents in each group of subordinates (staff nurses) and nurse manager's group (first-line nurse manager). The scale total score ranges from 16 to 112 , with higher total scores reflecting greater emotional intelligent managers.

\section{Tool (II): The Multifactor Leadership}

\section{Questionnaire (MLO 360 degree feedback)}

The Multifactor Leadership Questionnaire (MLQ 360 degree feedback) full-range model developed by Bass and Avolio (2004) was used to assess leadership effectiveness ${ }^{(18)}$. It comprises 45 items that load on to four dimensions:

- Transformational leadership style which includes Idealized attributes, Idealized behaviors, Inspirational motivation, Intellectual simulation and Individualized consideration (20 items).

- Transactional leadership style which includes contingent reward and management-by-exception "active" (8 items).

- Passive/Avoidant leadership style which includes management-by-exception "passive" and laissez-faire (8 items). 
- Outcomes of leadership which include extra effort, effectiveness and Satisfaction with leadership (9 items).

The questionnaire responses were measured on a five point likert scale ranging from " 0 " (not at all) to "4" (frequently). Scores were calculated for each of the four subscales by the mean scores of respondents in each group of subordinates (staff nurses) and nurse manager's group (first-line nurse managers). The overall score ranges from 45 to 180 , the higher the score, the greater success of effective leader.

In addition, socio-demographic characteristics for first-line nurse managers, and staff nurses; such as: age, marital status, unit, department, nursing qualifications, and experience were also measured/surveyed.

\section{Method}

An official permission was obtained from the identified setting to collect the required data. The research tools were translated into Arabic, and tested by "five" experts from the Faculty of Nursing, Alexandria University for its translation and content validity. Accordingly, some statements were restated until accepted as valid. A pilot study for the questionnaires was carried out on $10 \%$ of the hospital nursing staff $(\mathrm{N}=20)$. These were not included in the study subjects. This was done in order to check and ensure clarity of tools, identify obstacles and problems that may be encountered during data collection. Based on the pilot study no modification was done. The questionnaires were tested for its reliability using the Cronbach's alpha, to measure the internal consistency of the items composing each dimension of the tool "1" and tool " 2 ". Cronbach's alpha results revealed a strong reliability of both tools $(\mathrm{r}=0.953)$. Data were collected from the identified subjects through self-administrated questionnaire in their work settings to determine the relationship between emotional intelligence and effective leadership of the first-line nurse managers. Data were collected in a period of 4 weeks from $15 / 4 / 2012$ to $15 / 5 / 2012$.

\section{Ethical Considerations:}

Ethical considerations were respected throughout the study process. Subjects' informed consents were secured and their data confidentiality were assured through keeping their anonymity.

\section{Results}

The research results were presented according to the types of the questionnaire in an attempt to provide answers to the research questions.

Table (1) shows the socio-demographic characteristics of first-line nurse managers and staff nurses. The highest percentage of the study subjects $(56.3 \%)$ were working in surgical units, distributed as $59.5 \%$ staff 
nurses, and $39.5 \%$ first-line nurse mangers. The lowest percentage of them $(43.7 \%)$ were working in medical units, distributed as $40.5 \%$ staff nurses, and $60.5 \%$ first-line nurse managers. As regards to the age of the study subjects, about one third of staff nurses(36.5\%) were in the age group "30 - 39 years", as compared to only $11 \%$ at the age group "50 - 59 years". The highest percentage of first-line nurse mangers (55.3) were in the age group "40 - 49 years”, followed by $39.5 \%$ in the age group "50 - 59 years", and then $5.3 \%$ in the age group " 30 - 39 years."

Regarding years of experience in nursing practice, a highest percentages of staff nurses (36.5\% \& 33\%) having "10 - 19" and "20 29" years of nursing experience respectively, while the majority of first-line nurse mangers $(42.1 \%$ \& 39.5\%) having " 20 - 29" and "30 39" years of nursing experience. Concerning educational qualification, a highest percentage of the study subjects $(83.6 \%)$ were holding a diploma of secondary technical nursing school, distributed as $89.0 \%$ of staff nurses, and $55.3 \%$ of first-line nurse managers. The lowest percentage of them (2.9\%) were holding diploma of technical health institute. Most of the first-line nurse managers (42.1\%) had bachelor science of nursing as compared to $8 \%$ only of staff nurses.

As regards the study subjects' marital status, a highest percentage of them (73.5\%) were married, among them $86.8 \%$ were firstline nurse managers as compared to $71.0 \%$ staff nurses. The single nurses constituted $20.6 \%$ of the subjects, among them $23 \%$ were staff nurses as compared to $7.9 \%$ of the firstline nurse managers.

Table (2) shows a significant difference between the staff nurses' and first-line nurse managers' perceptions regarding total emotional intelligence $(\mathrm{Z}=4.231, \mathrm{p}=$ $<0.001)$. The first-line nurse mangers rated themselves highest in self-emotions appraisal (82.89 \pm 16.51$)$, in others-emotions appraisal where the mean score percent was $82.99 \pm$ 15.68 , in regulation of emotion where the mean score percent was $81.48 \pm 14.90$, and in use of emotion where mean score percent was $79.51 \pm 16.54$. On the other hand, the mean score percent of the staff nurses were $68.48 \pm$ $18.72,71.09 \pm 19.67,71.73 \pm 18.41, \& 70.75 \pm$ 19.05 respectively. Statistical significant differences were found between the two groups where $\mathrm{Z}=5.074, \mathrm{p}=<0.001, \mathrm{Z}=$ 3.769, $\mathrm{p}=<0.001, \mathrm{Z}=2.890, \mathrm{p}=0.004, \& \mathrm{Z}=$ $3.258, \mathrm{p}=0.001$ respectively.

Table (3) presents perception of the staff nurses and the first-line nurse mangers regarding the effective leadership of the firstline nurse managers. The mean score percent of total effective leadership from the staff nurses' perspectives was $55.79 \pm 12.50$ as compared to $59.42 \pm 9.94$ of the first-line nurse 
managers' perspectives. However, no statistical significant difference was detected.

In relation to transformational leadership style, the first-line nurse managers scored higher than the staff nurses $(71.34 \pm 15.92 \&$ $60.08 \pm 17.47$ respectively), with a statistical significant difference $(\mathrm{t}=3.692, \mathrm{p}=$ $<0.001)$. This was also true for all its subscales. Concerning "Transactional leadership style", first-line nurse managers had mean percent score of $59.95 \pm 13.19$ as compared to $57.60 \pm 15.72$ of the staff nurses, with no statistical significant difference between both groups.

As regards to "passive-avoidant leadership style", staff nurses had mean percent score of $38.62 \pm 24.01$ as compared to $18.75 \pm 14.65$ of first-line nurse mangers, with a statistical significant difference between them $(t=4.933$, $\mathrm{P}=<0.001)$. In relation to "outcomes of leadership" staff nurses had mean percent score of $59.86 \pm 18.42$ as compared to $68.64 \pm 13.98$ of the first-line nurse mangers. The difference was statistical significant between them where $\mathrm{t}=2.788, \mathrm{P}=<0.001$.

Table (4) shows the correlation between first-line nurse managers' emotional intelligence and their leadership styles. A positive correlation was found between firstline nurse managers' emotional intelligence and transformational leadership style, transactional leadership style, and outcomes of leadership. A negative correlation was found between first-line nurse managers' emotional intelligence and passive-avoidant leadership style. As well, the highest correlation was proved between transformational style and emotional intelligence of first-line nurse managers $(r=0.743, p<0.001)$, followed by outcomes of leadership $(r=0.552, p<0.001)$, next to them transactional style $(r=0.544$, $\mathrm{p}<0.001$ ), while the lowest correlation was between passive-avoidant style and emotional intelligence $(r=-0.341, p<0.001)$.

Table (5) presents the relation between the first-line nurse managers' years of nursing experience, and marital status and their perceptions of emotional intelligence. A statistical significant relation was found only between the first-line nurse managers' years of nursing experience and their perception regarding "self-emotions appraisal" $(\mathrm{F}=3.869$, $\mathrm{P}=.030$ ). In addition, a statistical significant relation was found only between the first-line nurse managers' marital status and their perceptions regarding "Self-emotions appraisal", "Regulation of emotion", and total emotional intelligence $(\mathrm{F}=4.042, \mathrm{P}=.015$, $\mathrm{F}=6.173, \quad \mathrm{P}=.002, \quad \mathrm{~F}=3.783, \quad \mathrm{P}=.019$ respectively).

\section{Discussion}

Emotional intelligence as measured in health care performing organizations is a key aspect to leadership effectiveness and individual and organizational success. Each 
effective leadership style draws on different emotional intelligence abilities; the best leaders are able to use the right approach in the right moment, and actively move from one approach to another as the situation is needed. People who lack the underlying abilities of emotional intelligence have a narrowed leadership repertoire, and so are too often caught relying on a style that is not strongly matched to the challenge of the moment ${ }^{(1,21)}$. This study aimed to determine the relationship between emotional intelligence and effective leadership of the first-line nurse managers.

Nurses and first-line nurse managers in this study perceived that the first-line nurse managers had a moderate level of overall emotional intelligence which is consistent with previous studies findings ${ }^{(22,23)}$. This could be explained in the light of $87 \%$ of the first-line nurse managers are married, as the married FLNM was obtained a high mean percent score for their "total emotional intelligence, with a statistical significant relation between their marital status and their "EI". This finding is consistent with $\operatorname{Palmer}(2001)$, and Kafetosios (2008)who reported that there is highly significant relation between people emotional intelligence and their marital status that have effect on their life satisfaction ${ }^{(24,25)}$. In addition, Asan and Ozyer (2003) stated that personal and social life through empowerment methods "achieve their effects by equipping people with the requisite knowledge, skills, and resilient self-beliefs of efficacy to alter aspects of their lives over which they can exercise some control"(26).

Furthermore, the moderate level of overall emotional intelligence and the high level of each dimension of emotional intelligence of FLNM might be attributed to the fact that they are usually more experienced nurses. The results of the current study showed a statistical significant relation between years of experience and "self-emotion appraisal" as self-emotion appraisal was perceived significantly higher as years of experience increased. Needless to say that sharing in different managerial settings and workshops, committees, and sharing in rules regulation in the health care organization can build up and added to their self-emotions appraisal. All of the previous activities probably helped them to become more competent, have power, knowledgeable, and more flexible in dealing with their nursing staff and their supervisors in their work environment. This finding is expected as the first-line nurse managers become more confident in themselves and have a realistic self-awareness as they can appraise and express their self-emotions which relate to their ability to understand their deep emotions and express them naturally. This finding revealed that self-emotions appraisal can evolve from years of experience. This was supported by Freshwater and Stickley (2002) 
who reported that as managers increase in age and experience, they become more knowledgeable and accepting accessing the sources of power, also their level of selfconfidence and their recognition of their emotions increase ${ }^{(27)}$. Such finding goes in line with several researches findings which reported that the familiarity with work have an impact on the managers' self- awareness and their intrapersonal skills ${ }^{(6,7,28)}$.

However, a study that examined the relationship between emotional intelligence and job stress on nurses, reported that emotional intelligence not differ according to age, gender and marital status variants ${ }^{(29)}$.

The increasingly complex environment in health care services requires the first-line nurse manager to have leadership abilities to manage this role in his or her organization. Therefore there is an obligation on nurse leaders and organizations to ensure that nurses are prepared and supported in this role. ${ }^{(6)}$ Subjects in this study perceived that the first-line nurse managers had a moderate level of effective leadership, a finding that is consistent with several studies ${ }^{(30,31)}$. At the same time the nurses gave FLNM the highest rate in transformational leadership style. As a high percentage of them stated that "the firstline nurse manager acts in ways that build others' respect for him/her". As well, most of them have a moderate mean percent regarding the transactional leadership style, since high percentage of them stated that "The first-line nurse managers express satisfaction when others meet expectations". Meanwhile, most of the study subjects rated them lowest in the "passive-avoidant leadership style". Moreover, most of study subjects had a moderate mean percent regarding the outcomes of leadership, since high percentage of them stated that "The first-line nurse manager increase others' willingness to try harder, is effective in meeting others' job related needs, and work with others in a satisfactory way". This was expected as the FLNM had a moderate level of emotional intelligence was statistically correlated to effective leadership.

This level of emotional intelligence contribute to the effective leadership of FLNM as they deal with work related changes, have a sense of power and confidence, instill pride in others who are associated with them. They also consider the moral and ethical consequences of decisions; focus on the importance of having sense of vision, talk enthusiastically about what needs to be accomplished. As well, they get others to look at problems from different angles, suggest new ways on how to complete assignments, help others, and consider the individual difference in needs and abilities. This implies behaviors which increase the willingness of the nursing staff to work harder and more than expected with sense of satisfaction. 
In this respect, Baumann \& Kolotylo (2009), Bondas (2006), and Ferguson (2011) stated that effective leadership is not assessed by accomplishment but rather on how leaders respond to day-to-day situations and inspire others. They assert that transformational leaders motivate their followers to do more than they really expect they can do, increase their sense of importance and value of the tasks, stimulate them to surpass their own interests and direct themselves to the interests of the team, organization or larger community and raising the level of change to a higher level ${ }^{(31-33)}$.

Moreover, Hoyle (2008) reported that effective leaders are the ones that earn the trust of their followers. One of the key reasons why followers are motivated by transformational leaders to perform beyond expectations is that followers respect and trust them ${ }^{(34)}$. It was confirmed that transformational leadership behavior was on average, highly positively correlated with subordinates' satisfaction, extra effort, and effectiveness, and whereas transactional leadership was generally viewed as being positively linked to performance outcomes $^{(35)}$.

Surprisingly, the findings of the current study revealed no statistical significant difference between the perception of staff nurses and first-line nurse managers regarding the total score of effective leadership of
FLNM. In other words, the perception of the two parties is nearly close to each other.

Moreover, the finding of the present study indicated that there is a significant positive correlation between first-line nurse managers' emotional intelligence and their effective leadership and a negative correlation with the passive-avoidant leadership style. This finding may be due to the fact that first-line nurse managers who use transformational behaviors motivate their staff nurses to do more than is expected, arouse heightened awareness in the group or organization, and de-emphasize narrow self-interest and rationality. They put an emphasis on moving with subordinates from merely existing and producing, to promoting their growth and unique contributions. These processes are thought to be largely dependent upon the evocation, framing and mobilization of emotions. The first-line nurse managers who avoid responsibility, who are absent when required, who fail to follow up on requests for assistance and resist expressing their opinion on important issues were more likely to possess poor emotional intelligence.

Goleman et al. (2002) and David (2007) believed that having a larger repertoire of emotional intelligence strengths can make a leader more effective because it means that the leader is flexible enough to handle the wideranging demands of running an organization. Emotional intelligence as measured in high 
performing organizations is a key aspect to leadership effectiveness and individual and organizational success. A successful leader inspires and motivates others, promotes a positive work environment, perceives and understands emotions, fosters an organizational climate where challenging opportunities are turned into successes and so forth. In other words, it is the leader's skills that are capable of motivating and encouraging subordinates to contribute to the effectiveness and success of the organization as a whole. Additionally, effective leadership of first-line nurse managers appears to depend on their ability to be aware of and understand their own emotions which represents a critical starting point in developing the skills of emotional intelligence $^{(7,36)}$.

In this respect, Goleman (2006) and Sosik (2007) claimed that the greater leaders' emotional intelligence, the better leaders are at managing strong relationship using emotion, and the better able they are to demonstrate effective performance. Moreover the first-line nurse managers should trust their intuition, be able to successfully manage social situations, and demonstrate empathic concern for others. In addition, when implementing emotional intelligence in a managerial situation, positive interpersonal relationship are fostered as leadership moves away from being coercive and authoritative and adopts more humanistic principles, promoting the organizational health and climate of the organization and building on mutual trust ${ }^{(37,38)}$. In line with the theoretical expectations, Caruso (2002) suggested that the individuals' level of emotional intelligence related significantly to what can be considered effective and ineffective leadership in terms of leadership behavior and the outcomes of leadership. This supports the assumption that effective leadership can have its roots in managing emotions $^{(39)}$.

In addition, Lewis (2011) concluded that emotional intelligence relates significantly to leadership behavior and the outcomes of leadership that are considered either effective or ineffective in a rapidly changing environment. He also added that the level of emotional awareness and the management of emotions in oneself and others influence the level of commitment and involvement of a leader with an individual follower. This involvement enables a leader to influence the behavior of an individual follower in order to raise his level of performance. Such a leader is able to instill trust and commitment, as he/she understands the underlying emotions associated with individual behavior. Secondly, such a leader is able to inspire followers to exert extra effort, which in turn results in a higher level of satisfaction for followers ${ }^{(40)}$. In this respect, Michael (2010) reported that transformational leadership directly and positively predicted organizational 
performance over and beyond the passiveavoidant leadership. As such, the passiveavoidant leadership is negatively related to organizational innovation and outcomes ${ }^{(41)}$.

\section{Conclusion}

Effective leaders use their emotional intelligence not only to manage themselves but to effectively manage and direct others within the organization as well as the organization itself. Effective leaders, who repeatedly use their emotional intelligence competencies to drive leadership performance, will move their organizations forward and generate greater outcomes for organizations than leaders with lower levels of emotional intelligence.

Results of this study provide evidence to support the idea that emotional intelligence is related positively to the transformational and transactional leadership style, and leadership effectiveness. As the correlation found between emotional intelligence and effective leadership provides empirical support to previous researches that theorized a significant positive predictive relationship between the two constructs, while the passive-avoidant leadership style have a negative correlation with the first-line nurse managers' emotional intelligence. Effective leaders were identified as those who reported transformational and transactional rather than passive-avoidant leadership style.

\section{Recommendations}

Based on the findings of the present study, the following recommendations are suggested and directed to the different levels of administrators.

I. Developing emotional intelligence through the following:

1. Nurse administrators have to enhance the constructs of emotional intelligence and transformational/transactional leadership styles in a training environment to better prepare managers/supervisors for their jobs and train them on unconditional acceptance of self and others.

2. Enhance a healthy work environment with open communications through conducting a schedule for staff meeting with their managers in order to improve the ability of the managers to consider others' emotions.

3. It is imperative for first-line nurse managers to develop a future context based on the feedback they receive. This will provide a framework for ensuring that there is systematic and planned development.

4. Understanding and managing that change of behavior is a crucial part of the leader development. Change strategies could include practicing experimental interactions to demonstrate new behavior and note the observations of others 
(feedback) on how new leadership behavior is being experienced by followers.

5. Advocate an approach to stress reduction that includes learning to read emotional intelligence levels in others and developing their own emotional intelligence capacities.

6. Building motivation in others through giving time, creating empathy, fostering team building, and be open to new ideas and responding in a rational manner.

7. First-line nurse managers should be trained to:

a. Be able to build trust in their nursing staff, inspire power and pride in their nursing staff, by going beyond their own individual interests and focusing on the interests of the group and of its members and become reference models for their nursing staff.

b. Act with integrity, talk about their most important values and beliefs with their nursing staff, focus on a desirable vision, have high moral judgment, optimism and selfefficiency.

c. Inspire others and this inspiration can occur without the need for identification of nursing staff with the leader. Inspirational leaders articulate in simple ways, shared goals and mutual understanding of what is right and important, provide visions of what is possible and how to attain them and enhance meaning and promote positive expectations about what needs to be done.

d. Be able to coach subordinates, understand and share in others' concerns and developmental needs and treating each individual uniquely.

II. Further research studies to be conducted:

- Research in the health care settings regarding emotional intelligence and leadership style studies needs to be further assessed and compared to process improvement programs.

- Research needs to be conducted to see if there is a link between leaders' emotional intelligence and desired organizational outcomes, for example, reduced turnover, employee commitment, job satisfaction, and high value human resource (HR) practice.

- Explore the degree of emotional intelligence in leaders and their followers and its effect on the patient quality of health care.

- Future researches to explore which individual factors of emotional intelligence had the greatest impact on effective leadership.

- Research also should be conducted on emotional intelligence training programs and its effects on leadership effectiveness. 
Emotional Intelligence and Effective Leadership

Table 1: Socio-demographic characteristics of staff nurses and first-line nurse managers at Alexandria Main University Hospital

\begin{tabular}{|c|c|c|c|c|c|c|c|}
\hline \multicolumn{2}{|c|}{$\begin{array}{c}\text { Total } \\
(\mathbf{N}=\mathbf{2 3 8})\end{array}$} & \multicolumn{2}{|c|}{$\begin{array}{c}\text { First-line nurse } \\
\text { managers } \\
(\mathbf{N}=38)\end{array}$} & \multicolumn{2}{|c|}{$\begin{array}{c}\text { Nurses } \\
(\mathbf{N}=\mathbf{2 0 0})\end{array}$} & \multirow[t]{2}{*}{ Variables } & \\
\hline$\%$ & No & $\%$ & No & $\%$ & No & & \\
\hline $43.7 \%$ & 104 & $60.5 \%$ & 23 & $40.5 \%$ & 81 & Medical & \multirow{2}{*}{ Unit } \\
\hline $56.3 \%$ & 134 & $39.5 \%$ & 15 & $59.5 \%$ & 119 & Surgical & \\
\hline $21.8 \%$ & 52 & $.0 \%$ & 0 & $26.0 \%$ & 52 & $20-29$ & \multirow{4}{*}{ Age Group } \\
\hline $31.5 \%$ & 75 & $5.3 \%$ & 2 & $36.5 \%$ & 73 & $30-39$ & \\
\hline $31.1 \%$ & 74 & $55.3 \%$ & 21 & $26.50 \%$ & 53 & $40-49$ & \\
\hline $15.6 \%$ & 37 & $39.5 \%$ & 15 & $11.0 \%$ & 22 & $50-59$ & \\
\hline $15.6 \%$ & 37 & $.0 \%$ & 0 & $18.5 \%$ & 37 & $1-9$ & \multirow{4}{*}{$\begin{array}{c}\text { Years of } \\
\text { experience in } \\
\text { nursing }\end{array}$} \\
\hline $33.6 \%$ & 80 & $18.4 \%$ & 7 & $36.5 \%$ & 73 & $10-19$ & \\
\hline $34.4 \%$ & 82 & $42.1 \%$ & 16 & $33.0 \%$ & 66 & $20-29$ & \\
\hline $16.4 \%$ & 39 & $39.5 \%$ & 15 & $12.0 \%$ & 24 & $30-39$ & \\
\hline $13.5 \%$ & 32 & $42.1 \%$ & 16 & $8.0 \%$ & 16 & $\begin{array}{l}\text { Bachelor science } \\
\text { of nursing }\end{array}$ & \multirow{3}{*}{$\begin{array}{l}\text { Educational } \\
\text { qualification }\end{array}$} \\
\hline $2.9 \%$ & 7 & $2.6 \%$ & 1 & $3.0 \%$ & 6 & $\begin{array}{l}\text { Diploma of } \\
\text { technical health } \\
\text { institute }\end{array}$ & \\
\hline $83.6 \%$ & 199 & $55.3 \%$ & 21 & $89.0 \%$ & 178 & $\begin{array}{l}\text { Diploma of } \\
\text { secondary } \\
\text { technical nursing } \\
\text { school }\end{array}$ & \\
\hline $20.6 \%$ & 49 & $7.9 \%$ & 3 & $23.0 \%$ & 46 & Single & \multirow{4}{*}{ Marital statues } \\
\hline $73.5 \%$ & 175 & $86.8 \%$ & 33 & $71.0 \%$ & 142 & Married & \\
\hline $2.5 \%$ & 6 & $2.6 \%$ & 1 & $2.5 \%$ & 5 & Widow & \\
\hline $3.4 \%$ & 8 & $2.6 \%$ & 1 & $3.5 \%$ & 7 & Divorced & \\
\hline
\end{tabular}


Table 2: Staff nurses and first-line nurse managers' perception of the first-Line nurse managers' emotional intelligence

\begin{tabular}{|c|c|c|c|}
\hline \multirow[t]{2}{*}{ Emotional Intelligence Subscales } & \multicolumn{2}{|c|}{ Emotional Intelligence Mean Score \% } & \multirow[b]{2}{*}{ Test of significance } \\
\hline & Staff Nurses & $\begin{array}{c}\text { First-Line Nurse } \\
\text { Managers }\end{array}$ & \\
\hline - $\quad$ Self-emotions Appraisal & $68.48 \pm 18.72$ & $82.89 \pm 16.51$ & $\begin{array}{l}\mathbf{Z}=5.074 * * * \\
\mathbf{P}=(<0.001)\end{array}$ \\
\hline - Others-emotions Appraisal & $71.09 \pm 19.67$ & $82.99 \pm 15.68$ & $\begin{array}{l}\mathbf{Z}=3.769 * * * \\
\mathbf{P}=(<0.001)\end{array}$ \\
\hline - $\quad$ Regulation of Emotion & $71.73 \pm 18.41$ & $81.48 \pm 14.90$ & $\begin{array}{c}\mathbf{Z}=2.890 * * \\
\mathbf{P}=(0.004)\end{array}$ \\
\hline - Use of Emotion & $70.75 \pm 19.05$ & $79.51 \pm 16.54$ & $\begin{array}{c}\mathbf{Z}=3.258 * * * \\
\mathbf{P}=(0.001)\end{array}$ \\
\hline - Total emotional intelligence & $52.58 \pm 13.32$ & $61.35 \pm 10.44$ & $\begin{array}{l}\mathbf{Z}=4.231 * * * \\
\mathbf{P}=(<0.001)\end{array}$ \\
\hline
\end{tabular}

Z: for Mann Whitney test

Significant value at $<0.001$

Low emotional intelligence: (0\%-33.3\%)

Moderate emotional intelligence: (33.4\%-66.6\%)

High emotional intelligence: (66.7\%-100\%) 
Table 3: Perception of staff nurses and first-line nurse managers regarding first-Line nurse managers' effective leadership in inpatient care units

\begin{tabular}{|c|c|c|c|c|}
\hline \multirow[b]{2}{*}{$\mathbf{p}$} & \multirow[b]{2}{*}{ t-test } & \multicolumn{2}{|c|}{$\begin{array}{c}\text { Effective Leadership Perception } \\
\text { Mean Score \% }\end{array}$} & \multirow{2}{*}{ Effective Leadership Subscales } \\
\hline & & $\begin{array}{c}\text { First Line } \\
\text { Nurse Manager } \\
(38)\end{array}$ & Nurses (200) & \\
\hline$<0.001^{*}$ & $3.975^{*}$ & $76.15 \pm 15.90$ & $62.40 \pm 20.15$ & $\begin{array}{l}\text { 1. Transformational leadership style: } \\
\text { A. Idealized Influence-Attributed }\end{array}$ \\
\hline$<0.001^{*}$ & $3.581^{*}$ & $73.51 \pm 17.21$ & $61.78 \pm 18.74$ & B. Idealized Influence-Behavior \\
\hline $0.015^{*}$ & $2.446^{*}$ & $71.71 \pm 20.27$ & $61.68 \pm 23.67$ & C. Inspirational Motivation \\
\hline$<0.001^{*}$ & $4.781^{*}$ & $76.59 \pm 20.28$ & $59.09 \pm 20.76$ & D. Intellectual Stimulation \\
\hline$<0.001^{*}$ & $3.574^{*}$ & $67.76 \pm 15.75$ & $55.46 \pm 20.06$ & E. Individualized Consideration \\
\hline$<0.001^{*}$ & $3.692^{*}$ & $71.34 \pm 15.92$ & $60.08 \pm 17.47$ & Total transformational leadership style \\
\hline $0.006^{*}$ & $2.745^{*}$ & $72.86 \pm 18.56$ & $63.28 \pm 19.93$ & $\begin{array}{l}\text { 2. Transactional leadership style: } \\
\text { A. Contingent Reward }\end{array}$ \\
\hline 0.169 & 1.378 & $47.03 \pm 24.21$ & $51.93 \pm 19.24$ & B. Management by Exception- Active \\
\hline 0.388 & 0.865 & $59.95 \pm 13.19$ & $57.60 \pm 15.72$ & Total Transactional leadership style \\
\hline$<0.001^{*}$ & $4.358^{*}$ & $19.57 \pm 18.27$ & $37.93 \pm 24.70$ & $\begin{array}{l}\text { 3. Passive- avoidant leadership style: } \\
\text { A. Management by Exception- Passive }\end{array}$ \\
\hline$<0.001^{*}$ & $4.625^{*}$ & $17.92 \pm 18.21$ & $39.37 \pm 27.44$ & B. Laissez-Faire \\
\hline$<0.001^{*}$ & $4.933^{*}$ & $18.75 \pm 14.65$ & $38.65 \pm 24.01$ & Total Passive- avoidant leadership style \\
\hline 0.290 & 1.060 & $44.90 \pm 11.61$ & $42.40 \pm 13.63$ & $\begin{array}{l}\text { 4. Outcomes of leadership: } \\
\text { A. Extra-Effort }\end{array}$ \\
\hline$<0.001^{*}$ & $3.419^{*}$ & $77.96 \pm 17.72$ & $64.71 \pm 22.59$ & B. Effectiveness \\
\hline 0.1556 & 1.425 & $31.57 \pm 17.19$ & $27.56 \pm 15.65$ & C. Satisfaction with Leadership \\
\hline $0.006^{*}$ & $2.788^{*}$ & $68.64 \pm 13.98$ & $59.86 \pm 18.42$ & Total outcomes of leadership \\
\hline 0.092 & 1.690 & $59.42 \pm 9.94$ & $55.79 \pm 12.50$ & Total effective leadership \\
\hline
\end{tabular}


Emotional Intelligence and Effective Leadership

Table 4: The correlation matrix between all variables of emotional intelligence and effective leadership of the first-Line nurse managers.

\begin{tabular}{|c|c|c|c|c|c|c|c|c|c|c|}
\hline \multirow{2}{*}{$\begin{array}{c}\text { Total } \\
\text { effective } \\
\text { leadership }\end{array}$} & \multicolumn{4}{|c|}{ Effective leadership } & \multicolumn{5}{|c|}{ Emotional intelligence } & \multirow{2}{*}{$\begin{array}{c}\text { Emotional } \\
\text { intelligence } \\
\& \\
\text { Effective leadership }\end{array}$} \\
\hline & $\begin{array}{c}\text { Outcomes } \\
\text { of } \\
\text { leadershi } \\
p\end{array}$ & $\begin{array}{c}\text { Passive- } \\
\text { avoidant } \\
\text { leadership } \\
\text { style }\end{array}$ & $\begin{array}{l}\text { Transactiona } \\
\text { lleadership } \\
\text { style }\end{array}$ & $\begin{array}{l}\text { Transforma- } \\
\text { tional } \\
\text { leadership } \\
\text { style }\end{array}$ & $\begin{array}{l}\text { Regulation } \\
\text { of } \\
\text { emotions }\end{array}$ & $\begin{array}{l}\text { Use of } \\
\text { emotions }\end{array}$ & $\begin{array}{l}\text { others- } \\
\text { emotions } \\
\text { appraisal }\end{array}$ & $\begin{array}{c}\text { Self- } \\
\text { emotions } \\
\text { appraisal }\end{array}$ & & \\
\hline $0.579^{* * * * *}$ & $0.475^{* * * *}$ & $-0.310^{k * * *}$ & $0.454^{* * *}$ & $0.689^{* * * *}$ & $0.820^{p+4+4}$ & $0.704^{3 * 5}$ & $0.859^{8 * 4}$ & & $\mathrm{r}$ & \multirow{2}{*}{$\begin{array}{c}\text { Self-emotions } \\
\text { appraisal }\end{array}$} \\
\hline$<0.001$ & $<0.001$ & $<0.001$ & $<0.001$ & $<0.001$ & $<0.001$ & $<0.001$ & $<0.001$ & & $\mathrm{P}$ & \\
\hline $0.611^{* * * *}$ & $0.545^{* * *}$ & $-0.369^{* * *}$ & $0.538^{* * * *}$ & $0.722^{* * * *}$ & $0.851^{* * *}$ & $0.763^{* * * *}$ & & & $\mathrm{r}$ & \multirow{2}{*}{$\begin{array}{l}\text { Others-emotions } \\
\text { appraisal }\end{array}$} \\
\hline$\langle 0.001$ & $<0.001$ & $\langle 0.001$ & $\langle 0.001$ & $\langle 0.001$ & $<0.001$ & $<0.001$ & & & $\mathrm{P}$ & \\
\hline $0.588^{8 * * *}$ & $0.506^{* * *}$ & $-0.264^{* * * *}$ & $0.512^{* * *}$ & $0.644^{* * * *}$ & $0.760^{* * 4}$ & & & & $\mathrm{r}$ & \multirow{2}{*}{ Use of emotions } \\
\hline$<0.001$ & $<0.001$ & $\langle 0.001$ & $\langle 0.001$ & $\langle 0.001$ & $\langle 0.001$ & & & & $\mathrm{p}$ & \\
\hline $0.555^{* * *}$ & $0.502^{* * *}$ & $-0.318^{* * * *}$ & $0.467^{* * * *}$ & $0.640^{* * * *}$ & & & & & $\mathrm{r}$ & \multirow{2}{*}{$\begin{array}{l}\text { Regulation of } \\
\text { emotions }\end{array}$} \\
\hline$<0.001$ & $<0.001$ & $<0.001$ & $<0.001$ & $<0.001$ & & & & & $\mathrm{P}$ & \\
\hline $0.878^{* * *}$ & $0.702^{* * *}$ & $-0.371^{* * *}$ & $0.643^{* * *}$ & & & & & & r & \multirow{2}{*}{$\begin{array}{l}\text { Transformational } \\
\text { leadership style }\end{array}$} \\
\hline$<0.001$ & $<0.001$ & $<0.001$ & $<0.001$ & & & & & & $\mathrm{P}$ & \\
\hline $0.806^{* * *}$ & $0.498^{* * *}$ & 0.032 & & & & & & & $\mathrm{r}$ & \multirow{2}{*}{$\begin{array}{l}\text { Transactional } \\
\text { leadership style }\end{array}$} \\
\hline$<0.001$ & $<0.001$ & 0.602 & & & & & & & $\mathrm{P}$ & \\
\hline 0.036 & $-0.271^{* * * * 4}$ & & & & & & & & $\mathrm{r}$ & \multirow{2}{*}{$\begin{array}{l}\text { Passive-avoidant } \\
\text { leadership style }\end{array}$} \\
\hline 0.555 & $<0.001$ & & & & & & & & $\mathrm{p}$ & \\
\hline $0.775^{* * * *}$ & & & & & & & & & $\mathrm{r}$ & \multirow{2}{*}{$\begin{array}{l}\text { Outcomes of } \\
\text { leadership }\end{array}$} \\
\hline$<0.001$ & & & & & & & & & $\mathrm{p}$ & \\
\hline $0.646^{* * *}$ & $0.552^{* * *}$ & $-0.341^{3 * * 4}$ & $0.544^{3 * x+4}$ & $0.743^{* * * *}$ & $0.879^{p+4+4}$ & $0.890^{8 * 4}$ & $0.944^{8 * t}$ & $0.927^{2 * 8 \pi}$ & $\mathrm{r}$ & \multirow{2}{*}{$\begin{array}{l}\text { Total Emotional } \\
\text { Intelligence }\end{array}$} \\
\hline$<0.001$ & $<0.001$ & $<0.001$ & $<0.001$ & $<0.001$ & $<0.001$ & $<0.001$ & $<0.001$ & $<0.001$ & $\mathrm{p}$ & \\
\hline
\end{tabular}


Emotional Intelligence and Effective Leadership

Table 5: The relationship between First-Line nurse managers' emotional intelligence (as perceived by them and their staff nurses and study subjects' years of nursing experience, and marital status.

\begin{tabular}{|c|c|c|c|c|c|c|}
\hline Emotional intelligence & \multicolumn{6}{|c|}{ Years of nursing experience of the first Line Nurse Managers (N=38) } \\
\hline \multirow{2}{*}{ - Self-emotions Appraisal (Mean Score \% \& SD) } & $\begin{array}{l}10-19 \\
(\mathrm{~N}=7)\end{array}$ & \multicolumn{2}{|c|}{$\begin{array}{l}20-29 \\
(\mathrm{~N}=16)\end{array}$} & $\begin{array}{l}30-39 \\
(\mathrm{~N}=15)\end{array}$ & $\begin{array}{c}\text { Total } \\
(\mathrm{N}=38)\end{array}$ & Test of significance \\
\hline & $68.36 \pm 27.9$ & \multicolumn{2}{|c|}{$86.83 \pm 6.98$} & $85.47 \pm 14.25$ & $82.89 \pm 16.50$ & $\begin{array}{l}(\mathrm{F}=3.869) \\
(\mathrm{P}=030)^{*}\end{array}$ \\
\hline & \multicolumn{6}{|c|}{ Marital status of the first-line nurse managers $(\mathrm{N}=38)$} \\
\hline & $\begin{array}{l}\text { Single } \\
(\mathrm{N}=3)\end{array}$ & $\begin{array}{l}\text { Married } \\
(\mathrm{N}=33)\end{array}$ & $\begin{array}{l}\text { Widow } \\
(\mathrm{N}=1)\end{array}$ & $\begin{array}{c}\text { Divorced } \\
(\mathrm{N}=1)\end{array}$ & $\begin{array}{l}\text { Total } \\
(\mathrm{N}=38)\end{array}$ & Test of significance \\
\hline - Self-emotions Appraisal & $83.33 \pm 2.06$ & $\begin{array}{l}84.30 \pm \\
15.22\end{array}$ & $85.71 \pm .00$ & $32.14 \pm .00$ & $\begin{array}{c}82.89 \pm \\
16.50\end{array}$ & $\begin{array}{l}(\mathrm{F}=4.042) \\
(\mathrm{P}=0.015)^{*}\end{array}$ \\
\hline - Regulation of Emotion & $\begin{array}{c}80.95 \pm \\
10.30\end{array}$ & $\begin{array}{l}83.00 \pm \\
12.62\end{array}$ & $85.71 \pm .00$ & $28.57 \pm .00$ & $\begin{array}{l}81.48 \pm \\
14.89\end{array}$ & $\begin{array}{l}(\mathrm{F}=6.173) \\
(\mathrm{P}=002)^{* *}\end{array}$ \\
\hline - Total emotional intelligence & $55.95 \pm 2.57$ & $62.77 \pm 9.70$ & $59.82 \pm .00$ & $32.14 \pm .00$ & $\begin{array}{l}61.34 \pm \\
10.44\end{array}$ & $\begin{array}{l}(\mathrm{F}=3.783) \\
\left(\mathrm{P}=0.019^{*}\right)\end{array}$ \\
\hline
\end{tabular}




\section{References}

1. Anthony P. Ronald M. Emotional intelligence, leadership effectiveness and team outcomes. The international journal of organizational analysis 2003; 11 (1): 21-40. Available at: http://www.emeraldinsight.com/journals.ht m?articleid $=1664945 \&$ show $=$ abstract.

(Retrieved on February 2013).

2. Jordan P, Ashkanasy N. Emotional intelligence as a mediator of emotional and behavioral reactions to job insecurity. Published Doctoral Dissertation, Academy of Management Review. January 2002; 72, 361-372.

3. Wong C, Law K. The construct and criterion validity of emotional intelligence and its potential utility for management studies. Journal of Applied Psychology 2004; 89: 483-96. Available at: www.eiconsortium.org/measures/weis.htm 1. (Retrieved on December 2011).

4. Rosete D, Ciarrochi J. A critical evaluation of the role of emotional intelligence in leadership effectiveness. Published Doctoral Dissertation, University of Wollongong, Australia, 2005. Available at: www.acceptandchange.com/.../rosete-andciarrochi-2005-lodj-EI-Le. (Retrieved on February 2013).
5. Loke C. Leadership behavior: effect on job satisfaction, productivity, and organizational commitment. Journal of Nursing Management 2001; 9(4): 191-204.

6. Roche E. Attributional processes of leaders in leader member interactions. Organizational Behavior and Human Performance 2009; 23(3): 429-58.

7. Goleman D, Boyatzis R, Mckee A. Primal leadership. Realizing the power of emotional intelligence. Boston: Harvard business school press, 2002.

8. Jeremy B. The relationship between emotionalsocial intelligence and Leadership practices among college student leaders. Published Doctoral Dissertation. Bowling Green State University. December 2005. Available at: http://etd.ohiolink.edu/view.cgi/Cavins\%2 0Bryan\%20Jeremy.pdf?bgsu1131374548. (Retrieved on December 2011).

9. Daniel R. Examining the relationship between emotional intelligence of managers and organizational commitment of subordinates. Published Doctoral Dissertation, North central University, Arizona. March 2011. Available at: http://proquest.umi.com/pqdlink?Ver $=1 \&$ Exp=11-142016\&FMT $=7 \& \mathrm{DID}=2338008741 \& \mathrm{RQT}$ $=309 \&$ attempt $=1$. (Retrieved on December 2011). 
10. Serrat O. Understanding and developing emotional intelligence. Knowledge solutions: Handy quick reference. June 2009. Available at: http://www.researchnest.com/all reports/1 3089062351understanding-developingemotional-intelligence.pdf. (Retrieved on February 2013).

11. Macik-Frey M. Communication-centered approach to leadership: The relationship of interpersonal communication competence to transformational leadership and emotional intelligence. Published Doctoral Dissertation, The University of Texas at Arlington, United States - Texas, 2007. Available at: dspace.uta.edu/bitstream/.../umi-uta1743.pdf?...1. (Retrieved on December 2011).

12. John T. Legier J. Assessing leadership effectiveness: the relationship between emotional intelligence and leadership behaviors on group and organizational performance. Published Doctoral Dissertation. Southern Illinois University Carbondale, 2007. Available at http://www.proquest.com. (Retrieved on February 2013).

13. Michael A. The role of emotional intelligence in transformational leadership style. Published Doctoral Dissertation. Capella University, USA, 2008. Available at: http://gradworks.umi.com/33/20/3320725. html. (Retrieved on February 2013).

14. Webb P. Ronald M. The relationship between individual personality orientation and executive leadership behavior. Journal of Occupational and Organizational Psychology2001; 71: 99-126. Available at:

http://www.emeraldinsight.com/journals.ht $\underline{\text { m?articleid }=1664945 \& \text { show }=\text { abstract. }}$. (Retrieved on February 2013).

15. Palmer B, Walls M. Emotional intelligence and effective leadership. MBC University Press. Leadership and organization development journal 2001; 22 (1): 5-10. Available at: http://en.scientificcommons.org/22236097. (Retrieved on February 2013).

16. Purkable T. Emotional intelligence, leadership style and coping mechanisms of executives. Published Doctoral Dissertation. Catholic University of America, 2003.

17. Cheryl L. The relationship of emotional intelligence and transformational leadership behavior in non-profit executive leaders. Published Doctoral Dissertation, Capella University. USA. 2007:1549.Available at: http://www.dhs.state.or.us/tools/vr/training /2007/eq_transleadership.pdf. (Retrieved on February 2013). 
18. Bass B. Avolio B. Multifactor Leadership Questionnaire "feedback 360 degree". USA, Mind garden, Inc. 2004. Available At:

http://www.mindgarden.com. (Retrieved on February 2013).

19. Abd El Rahman. R. the impact of first-line nurse managers' leadership development training program on workgroup climate and performance. Unpublished Doctoral Dissertation. Faculty of Nursing, Alexandria University, 2009.

20. Childs M. An exploration of a relationship between emotional intelligence and leadership potential. Journal of Managerial Psychology 2004: 18(7/8): 814-23.

21. Horner M. Leadership theory: past, present and future. In: Omer T. Leadership style of nurse managers at the Saudi National Guard Hospitals. Unpublished doctoral dissertation, College of Nursing and Health Science, George Mason University, Virginia, 2005. Available at: http://proqucst.umi.com/pqdweb?index $=0$ $\&$ did=765687341 $\&$ SrchMode $=1 \& \operatorname{sid}=: 5 \& \mathrm{~F}$ $\underline{\mathrm{mt}}=6 \& \mathrm{VInst}=\mathrm{PROD} \& \mathrm{VType}=\mathrm{PQD} \& \mathrm{RQT}$ $=309 \&$ VName $=P Q D \& R Q T=12542564$ 017\&clientId=45596. (Retrieved on March 2013).

22. Akterjodent J. Why 'emotional intelligence' will not predict leadership effectiveness: A comment on Prati,
Douglas, Ferris, Ammeter, and Buckley. The International Journal of Organizational Analysis 2008; 11(4): 35561.

23. Maree L. and Ellis M. On why 'emotional intelligence' will not predict leadership effectiveness beyond IQ or the "big five": An extension and rejoinder. Organizational Analysis. The Leadership Quarterly 2007; 12(2): 171-182.

24. Palmer B. Personal traits and leadership styles of Taiwan's higher educational institutions in innovative operations. Journal of American Academy of Business 2001; 12(2): 145-6.

25. Kafetosios J. Measuring emotional intelligence in adolescents. Personality and Individual Differences, 2008; 31: 1105-19.

26. Asan W, Ozyer M. Does emotional intelligence - as measured by the EQI influence transformational leadership and/or desirable outcomes? Leadership and Organizational Development Journal, 2003; 27(5): 330-51.

27. Freshwater N, Stickly O. Value congruence in leader-member exchange. Journal of Social Psychology, 2002; 137(5): 647-62. (Retrieved on March 2013)

28. Posner K. Leadership is the art of mobilizing others to want to struggle for shared aspirations. Leadership 
development resources. 2011. Available at:

www.drexel.edu/.../10\%20Commitments\% 20of\%20Leadership\%20-. (Retrieved on February 2013).

29. Adilogullari I. The teachers level of emotional intelligence some of the demographic variables for investigation. Educational Research and Reviews 2011; 6 (13): 786-92. Available at: http://www.academicjournals.org/ERR. (Retrieved on March 2013).

30. Bamford C. Meta-analytic review of leader-member exchange theory: Correlates and contrast issues. Journal of Applied Psychology 2003; 82(6): 827-44. (Retrieved on March 2013).

31. Baumann R, Kolotylo A. study of leadership. Character \& Personality; A quarterly for Psychodiagnostic \& Allied Studies 2009; 12, 285-9.

32. Bondas A. Congruence in job performance ratings: A study of 260 degree feedback examining self, manager, peers, and consultant ratings. Human Relations 2006; 51(4): 517-30.

33. Ferguson A. Emotion regulation in the workplace: A new way to conceptualize emotional labor. Journal of Health Psychology 2011; 5: 95-110.

34. Hoyle C. Emotional Intelligence and Leadership Behavior in Construction
Executives. Journal of Management in Engineering 2008; 22(3): 119-25.

35. Emmerling N,Goleman D. Studies in emotional intelligence redefines our approach to leadership development. Public Personnel Management 2003; 31(4): 523-30.

36. David V. Can emotional intelligence be measured and developed? Leadership \& Organization Development Journal 2007; 20(5): 242-52.

37. Goleman D. Emotional intelligence, Issues in paradigm building. In Cherniss $\mathrm{C}$, Golemen D. (Eds.): The emotionally intelligent workplace, How to select for, measures, and improve emotional intelligence in individuals, groups, and organizations. San Francisco, CA: JosseyBass, 2006.

38. Sosik M. Social and emotional intelligence: Starting a conversation about their similarities and differences. In Schulze R, Roberts R. (Eds.): Emotional intelligence. An international Handbook. Cambridge MA: Hogrefe\& Huber Publications, 2007.

39. Caruso L. "Models of emotional intelligence", In Sternberg R. (Ed.): Handbook of Intelligence, Cambridge University Press, Cambridge, 2002.

40. Lewis M. ""The influence of authenticity and emotional intelligence on the 
Emotional Intelligence and Effective Leadership

relationship between self-monitoring and leadership effectiveness.". Human

Resource Management Review 2011; 13 (5): 493-504.
41. Michael E. "An exploratory study of emotional intelligence in clinical nurses". Leadership\& Organization Development Journal, 2006; 26 (5): 388-99. 